\title{
Optimum Pavement Thickness for Rigid Pavement in UP Eastern Region
}

\author{
Shubham Pandey, A.K. Sachan, Anupam Rawat, Saurabh Singh
}

\begin{abstract}
Highways are important in the growth of the economy of the nation. Pavement distributes and reduces the loads to the subgrade so as not to destruct the pavement foundation and subgrade. Thermal stresses are more vulnerable and to be included as the ability to contract and expand concrete is very less. The roads provide vehicle access to various points in all weather conditions and provide road users with a clean, smooth, and comfortable ride without unnecessary delay or excessive wear and tear. Since the UP eastern region faces tremendous temperature differences, load variations, and moisture conditions. This paper puts an attempt to identify the optimum thickness of the rigid pavement to sustain these extreme temperature variations, high humidity, and various load configurations. In this paper the various configurations of the loads are taken from the IRC 6: 2016 along with the various moisture and temperature data are taken from the Indian Meteorological Department (IMD) ministry of Earth and Science government of India. The paper gives a brief idea of pavement thickness selection. This paper utilizes Finite Element Method (FEM) based Software's KENPAVE along with ANSYS 12.1 for a better understanding of the critical stress and its positions where the pavement needs attention in the design. All these varying conditions are incorporated in these software's and the results obtained were in the form of figures, graphs, and deflected shapes. Parametric variation in the pavement section (i.e. variation in thickness of PQC, DLC layer, and in Modulus of Elasticity), variation in poisons ratio and temperature by using these results and doing cost analysis the optimum pavement thickness was obtained.
\end{abstract}

Keywords: Rigid Pavement, Pavement Foundation, Climatic Conditions, Finite Element Method.

\section{INTRODUCTION}

Rigid pavements get their name from the fact that the pavement structure deflects very little under load due to the surface course's high modulus of elasticity (Srikanth M $\mathrm{R}, 2015)$. Due to its relative rigidity, a rigid pavement structure consists of a PCC surface course placed on top of either the underlying base course or a subgrade. The pavement system distributes loads over a vast area with only one, or at most two, structural layers.

Manuscript received on May 31, 2021.

Revised Manuscript received on June 06, 2021.

Manuscript published on June 30, 2021.

* Correspondence Author

Shubham Pandey*, Structural Engineering Department, Motilal Nehru National Institute of Technology Allahabad, Prayagraj (UP), India. Email: shubhampandeymnnit@gmail.com

Prof. A.K. Sachan, Structural Engineering Department, Motilal Nehru National Institute of Technology Allahabad, Prayagraj (UP), India. Email: sachan@mnnit.ac.in

Dr. Anupam Rawat, Structural Engineering Department, Motilal Nehru National Institute of Technology Allahabad, Prayagraj (UP), India. Email: anupam@mnnit.ac.in

Saurabh Singh, Structural Engineering Department, Motilal Nehru National Institute of Technology Allahabad, Prayagraj (UP), India. Email: singhsaurabh25596@gmail.com

(C) The Authors. Published by Blue Eyes Intelligence Engineering and Sciences Publication (BEIESP). This is an open access article under the CC BY-NC-ND license (http://creativecommons.org/licenses/by-nc-nd/4.0/)
The rigid pavement slab was modelled by Westergaard's as a thin elastic plate lying on a thick liquid soil sub-grade. As shown below, a typical portion of the rigid pavement.-

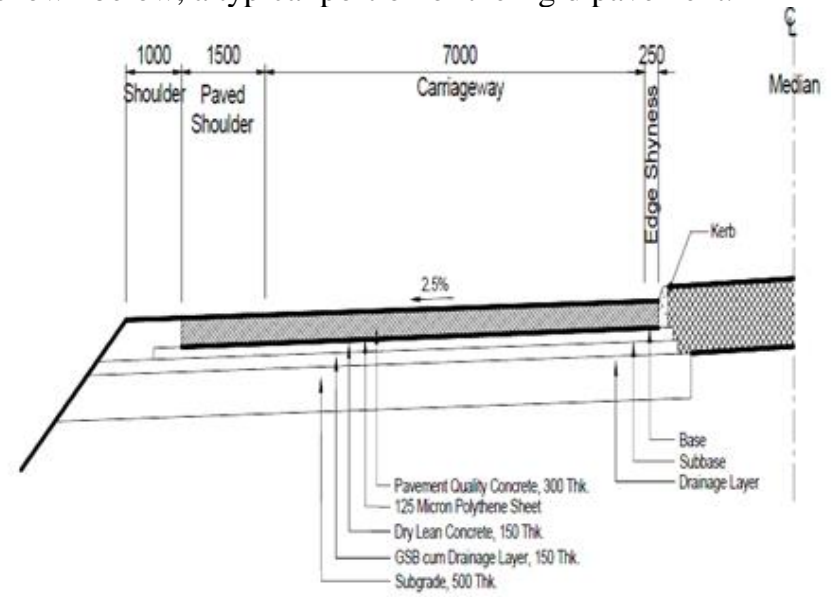

Fig 1 Typical section of the rigid pavement section (Huang, 2004)

\subsection{Basic Structural Elements}

\section{PQC LAYER (Pavement Quality Concrete)}

PQC is the first top layer of rigid pavement. For PQC, where strengths above 35 to $40 \mathrm{MPa}$ are generally specified, the following types of cement can be used:-

1. OPC, Grade 43 (IS: 8112)

2. OPC, Grade 53 (IS: 12269) to be used only when a part of cement (15-30 percent) is replaced by fly-ash.

The use of PPC (IS: 1489) or additives like ground granulated blast furnace slag (GG BS) (IS: 455) and fly ash is permitted in the current IRC. But, there is a need to permit the use of these, provided strength requirements are met.

\section{DLC (Dry Lean Concrete)-}

The base or sub-base layer's uniform support has a major effect on the performance of cement concrete pavement. Dry lean concrete is the most commonly used foundation under cement concrete pavement in India (DLC). A lean concrete mix with low water content in the range of $5-6 \%$ is mixed to produce the mix. As the mix looks almost dry, it is referred to as a dry lean concrete mix. A wet mix can always be compacted by a needle vibrator and subsequently leveled and finished. But in the case of the dry lean concrete base, compaction can be achieved only by vibratory effort. The mix, therefore, has to be compacted by vibratory rollers. Single or double drum rollers can be used for this purpose. Clause 601 of MOSRTH Specification deals with the DLC layer. Such a layer has been mandatory under cement concrete pavement for Highways as per IRC: 15-2002. (IRC-15.Pdf, n.d.)

\section{Published By:}

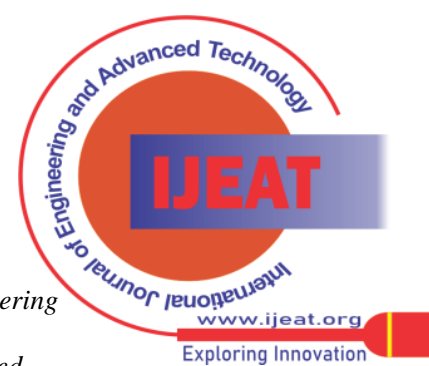




\section{DRAINAGE LAYER}

In India, it is now standard practice to have a drainage layer of granular material underneath the DLC. The most common grading system is as follows: -

Table 1: Coarse Graded Granular Sub-Base Materials Grading

\begin{tabular}{|l|l|l|l|}
\hline \multirow{2}{*}{$\begin{array}{c}\text { IS SIEVE } \\
\text { DESIGNATION } \\
(\mathbf{m m})\end{array}$} & \multicolumn{3}{|c|}{ Percent by weight passing the is sieve } \\
\cline { 2 - 4 } & Grading I & Grading II & Grading III \\
\hline 75 & & & \\
\hline 53 & 100 & & \\
\hline 26.5 & & 100 & \\
\hline 9.50 & $55-75$ & $50-80$ & 100 \\
\hline 4.75 & & & $25-45$ \\
\hline 2.36 & $10-30$ & $15-35$ & \\
\hline .425 & & & $<10$ \\
\hline .075 & & & 20 \\
\hline $\begin{array}{l}\text { CBR VALUE } \\
(m i n i m u m)\end{array}$ & 30 & 25 & \\
\hline
\end{tabular}

(Manjunatha, 2014)

SUBGRADE- Subgrade, infill sections, is generally defined as the top $500 \mathrm{~mm}$ of the embankment, and in cut sections, The natural land, graded and compacted, on which the pavement is constructed may be the subgrade. The subgrade, which determines the pavement's strength and stiffness, supports the cement concrete pavement, including the sub-base.

COVER SOIL - The local sand is used as the cover soil. After 7 days of moist curing, local soil or moored is stabilized with lime, lime-fly ash, or cement to achieve a minimum unconfined compressive strength of 1.7 MPa.

\section{Factor effecting the rigid pavement}

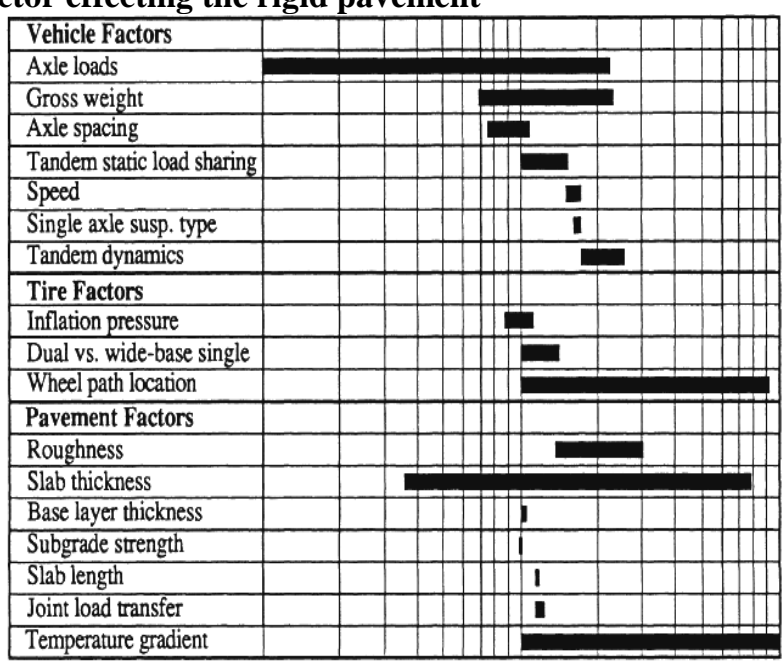

Fig 2 factors effecting the rigid pavement Type of loading(Huang, 2004)

IRC6 2000 specified that the standard load class is a class A type loading which is

Table 2 load and contact area

\begin{tabular}{|l|cc|}
\hline \multirow{2}{*}{$\begin{array}{c}\text { Axle load } \\
(\mathrm{kN})\end{array}$} & \multicolumn{2}{|c|}{ Ground contact area } \\
\cline { 2 - 3 } & $\mathrm{B}$ & $\mathrm{W}$ \\
\hline $11.4 \mathrm{kN}$ & $250 \mathrm{~mm}$ & $500 \mathrm{~mm}$ \\
\hline $6.8 \mathrm{kN}$ & $200 \mathrm{~mm}$ & $380 \mathrm{~mm}$ \\
\hline
\end{tabular}

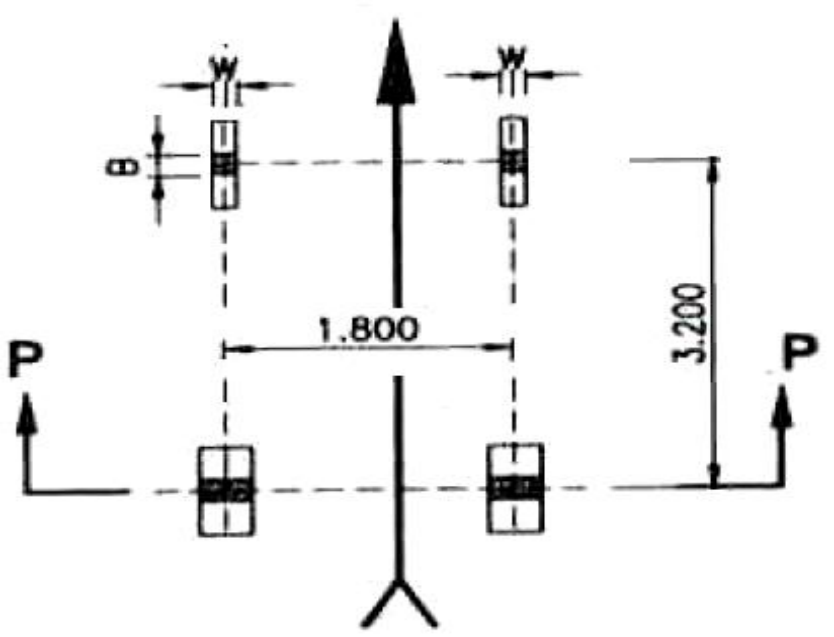

Fig 3: Wheel configuration(Indian Roads Congress, 2016)

\subsection{Finite Element Method (FEM)}

The finite element method is a method for computing the solution of a differential or integral equation (FEM). It's been used to solve a wide range of physical problems where the governing differential equations have been determined. The method involves assuming a piecewise continuous function for the solution and obtaining the parameters of the functions in such a way that the solution error is minimized. This article provides a basic understanding of the finite element process. To explain the technique, we'll use the plane stress and plane strain formulas. The Finite Element Method (FEM) is a computational iteration technique for measuring stress and displacements using a model that is computerized. The process was first used in the aerospace industry in the late 1960s and then in dentistry in the early 1970s. This approach may also be used to construct an analogous mathematical model of a real object with a complex form and multiple materials. The finite analysis is used to solve a complex problem by redefining it as the sum of a set of interconnected simpler problems. The first stage is to divide the complicated geometry into an appropriate set of smaller "elements" of "finite" dimensions, using the "mesh" framework of the researched structures. Each object has an internal strain feature that allows it to take on a distinct geometric form (square, triangle, tetrahedron, etc.). These functions, when combined with the element's actual geometry, can be used to find the equilibrium equations between external forces acting on the element and displacements that occur on its surface Nodes.

1. The nodal points' coordinates.

2. Each element's number of nodes.

3. The material's Poisson ratio and Young's modulus as modeled by various components.

4. The boundary conditions are number four.

5. The structure is subjected to external forces. 


\section{MODELLING}

\subsection{Introduction}

Our basic aim is to fix the position and dimension of rigid pavement. Modelling of the pavement is for the determination of the stress due to the loading. To determine these several trials are required. Hence rigid pavement is modelled and solved using ANSYS software and trails are taken till optimum reached.

\subsection{Software Descriptions}

ANSYS 12.1- Ansys 12.1 is a finite element-based program which is used a graphical interface for modeling the objects. Ansys gives numeric approximate results. The precision of results depends on the model type and mesh.

The following data is required by ANSYS for material properties: Elastic modulus is a measure of how flexible anything is (Ec). The Poisson's ratio (í) is a measure of how likely something is to happen. Density $(\rho)$ is a measure of how dense anything is.

KENPAVE-Kenpave software is the program developed at the University of Kentucky. Program is developed for the studies of pavement of both type's flexible pavement and rigid pavement. Both programs named KENLAYER and KENSLAB are part of KENPAVE software.

\section{KENLAYER}

Only flexible pavements with no joints or rigid layers are protected by the KENLAYER computer software. The solution for an elastic multilayer device under a circular loaded field is at the heart of KENLAYER. For several wheels, the solutions are superimposed, non-linear layers are applied iteratively, and viscoelastic layers are collocated at different times. KENLAYER can thus be used to represent layer structures under single, dual, dual-tandem, or dual-tridem wheels, with each layer operating differently, such as linear, nonlinear, or viscoelastic. For damage analysis, each year can be separated into up to 12 cycles, each with its own set of material parameters. There can be up to 12 load groups in each loop, which can be single or multiple. The damage induced by fatigue cracking and permanent deformation in each cycle is summed up across all load classes to compute the design life.(Huang, 2004)

KENSLABS The finite-element approach is used by the KENSLABS computer program (Huang, 1985) to segment the slab into rectangular finite elements with a large number of nodes. The slab is subjected to both wheel loads and subgrade reactions in the form of vertically oriented forces at the nodes.(Huang, 2004)

\section{ANALYSIS}

3.1 Descriptions of Problem an existing pavement portion of the LMNHP (Lucknow - Muzaffarpur National Highway Project) i.e. belongs to U.P. Eastern region, being implemented by the NHAI as part of the NHDP. The parameter for design is five layers of the pavement including the PQC layer

Table 3: Layer description

\begin{tabular}{|c|l|l|l|}
\hline Layer & Thickness (mm) & Length(mm) & Width(mm) \\
\hline PQC layer & 320 & 5000 & 9500 \\
\hline DLC layer & 150 & 5000 & 10300 \\
\hline $\begin{array}{c}\text { Drainage } \\
\text { layer }\end{array}$ & 200 & 5000 & 11000 \\
\hline
\end{tabular}

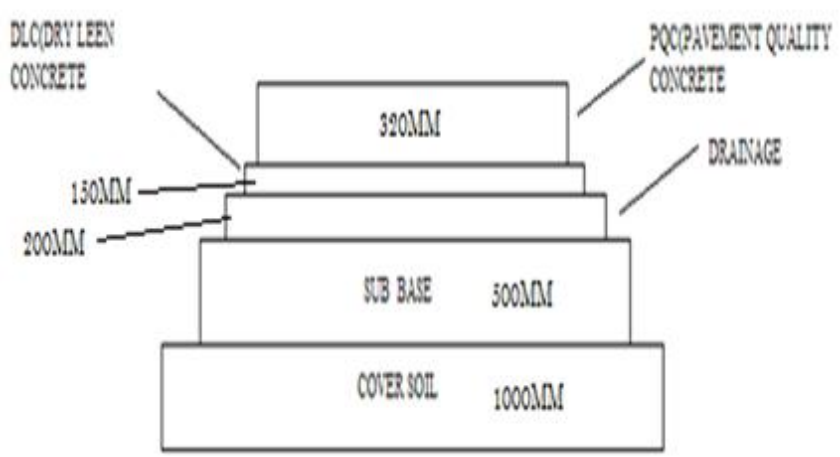

Fig 4 section of the rigid pavement $\mathrm{NH}-28$

\section{PROPERTIES OF MATERIALS}

Modelling in ANSYS 12.1

Table 4 table of properties of different layers

\begin{tabular}{|l|l|l|l|}
\hline \multicolumn{1}{|c|}{ Layer Type } & $\begin{array}{l}\text { Modulus of } \\
\text { elasticity }\end{array}$ & Poisson ratio & Density \\
\hline PQC & $3 \times 10^{7}$ & .15 & 2400 \\
\hline DLC & $2.5 \times 10^{7}$ & .15 & 2200 \\
\hline $\begin{array}{l}\text { DRAINAGE } \\
\text { LAYER }\end{array}$ & $1.2 \times 10^{7}$ & .22 & 1900 \\
\hline $\begin{array}{l}\text { SUBGRADE } \\
\text { LAYER }\end{array}$ & $22 \times 10^{7}$ & .22 & 2080 \\
\hline
\end{tabular}

Table 5 cover soil property

\begin{tabular}{|l|l|l|}
\hline $\begin{array}{l}\text { Layer } \\
\text { type }\end{array}$ & Thickness & Engineering property \\
\hline $\begin{array}{l}\text { Cover } \\
\text { soil }\end{array}$ & $1000 \mathrm{~mm}$ & $\begin{array}{l}\text { As location (Allahabad) Silt } \\
\text { sand E=13.8e10 , Poisson } \\
\text { ratio=0.4 }\end{array}$ \\
\hline
\end{tabular}

Type of load -class A type load is applied on the rigid pavement and wheel load of rear and front is as listed blow Front wheel- 6.8 ton

Rear wheel -11.4 ton

\section{Application of load on the pavement}

The figure shows the position of the load applied at different places in the pavement section. In the figure the pressure is applied at
A) $X=(3600,4100)$
$\mathrm{Y}=(0,250)$
B) $\mathrm{X}=(5400,5900)$
$\mathrm{Y}=(0,250)$
C) $X=(3660,4040)$
$\mathrm{Y}=(3225,3525)$
D) $X=(5460,5840)$
$\mathrm{Y}=(3225,3525)$
Surface area of load application

Table. 6 Surface area of load application(Indian Roads Congress, 2016)

\begin{tabular}{|l|l|l|l|}
\hline Sr.No. & LOAD & Intensity (KN) & $\begin{array}{l}\text { Ground Contact } \\
\left.\text { Area(mm }{ }^{2}\right)\end{array}$ \\
\hline 1. & A & 114 & $500 \times 250$ \\
\hline 2. & B & 114 & $500 \times 250$ \\
\hline 3. & C & 68 & $300 \times 380$ \\
\hline 4. & D & 68 & $300 \times 380$ \\
\hline
\end{tabular}

Published By:

Blue Eyes Intelligence Engineering and Sciences Publication

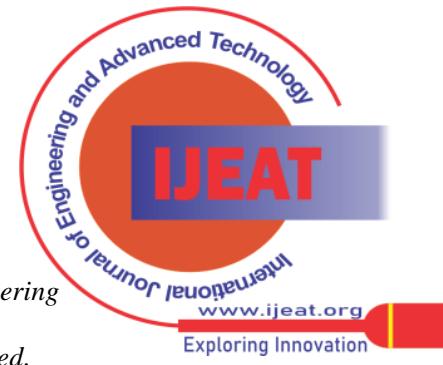


The load applied at various points in the pavement section is depicted in the table. The pressure is applied in the manner depicted in the diagram below

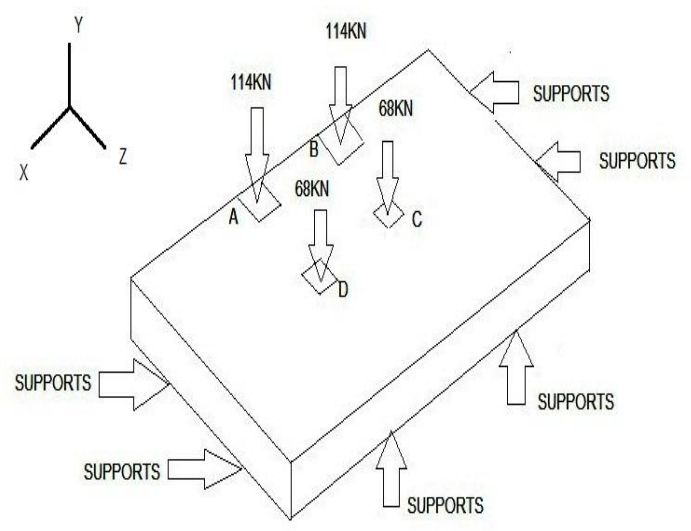

Fig 5- Loads and Foundation Type
Concrete properties the concrete used for the foundation is M40. Hence, Modulus of Elasticity $=3 \times 10^{10}$ $\mathrm{N} / \mathrm{m}^{2}$.Poisson's Ratio $=0.15$

\section{Case I Modeling In Kenpave}

Material properties are similar as in Ansys 12.1

Temperature in $\mathrm{C}$, force in $\mathrm{kN}$, length in $\mathrm{cm}$, unit weight in $\mathrm{kN} / \mathrm{m} 3$, tension in $\mathrm{kPa}$ and subgrade $\mathrm{K}$ value in $\mathrm{MN} / \mathrm{m} 3$

Finite Element Grid slab coordinates are:

$\mathrm{X}=95190 \quad 285 \quad 380 \quad 475 \quad 570665 \quad 760 \quad 855950$

$\mathrm{Y}=\begin{array}{llllllllll}50 & 100 & 150 & 200 & 250 & 300 & 350 & 400 & 450 & 500\end{array}$

\section{Different stress value in three conditions}

\section{FOR LOAD GROUP}

Table 7 coordinates of load area

\begin{tabular}{|c|c|c|c|c|c|}
\hline $\begin{array}{l}\text { SLA } \\
\text { B } \\
\text { NO. } \\
\text { (LS) }\end{array}$ & $\begin{array}{l}\text { X COORDI } \\
\text { (XL1) }\end{array}$ & & $\begin{array}{l}\text { Y COORD } \\
\text { (YL1) }\end{array}$ & (YL2) & $\begin{array}{r}\text { INTENSITY } \\
\text { (QQ) }\end{array}$ \\
\hline 1 & 360.00000 & 410.00000 & 0.00000 & 25.00000 & 11400.00000 \\
\hline 2 & 540.00000 & 590.00000 & 0.00000 & 25.00000 & 11400.00000 \\
\hline 3 & 366.00000 & 404.00000 & 322.50000 & 352.50000 & 6800.00000 \\
\hline 4 & 546.00000 & 584.00000 & 322.50000 & 352.50000 & 6800.00000 \\
\hline
\end{tabular}

Kenpave software provide only mathematical model no graphical output is available in it.

\section{Case II Modelling and results of ANSYS model}

Modelling Results of ANSYS

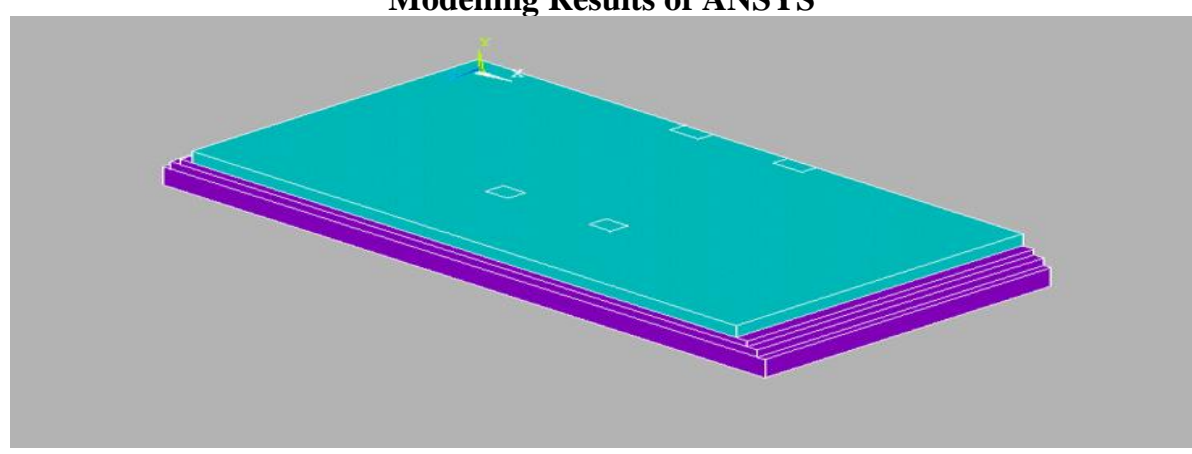

Fig 6 Model of the pavement

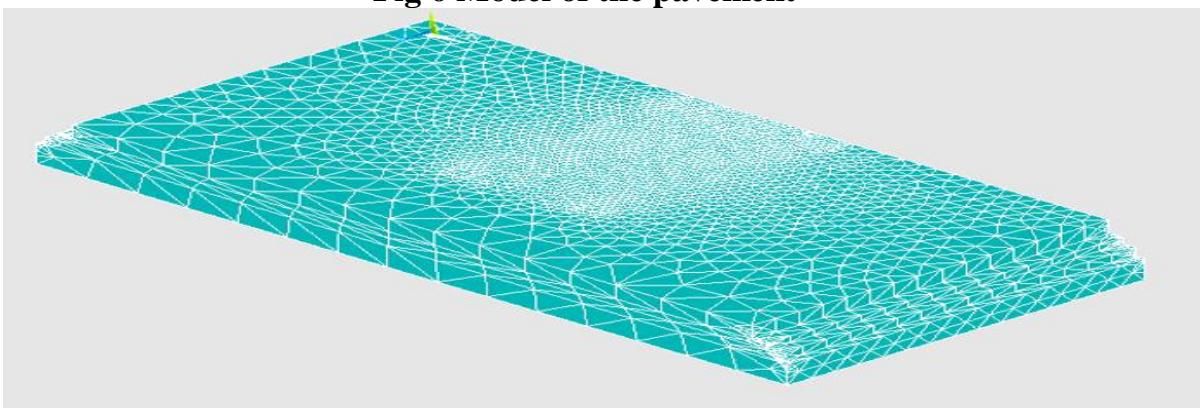

Fig 7 Meshing of model

Published By:

Blue Eyes Intelligence Engineering and Sciences Publication

(C) Copyright: All rights reserved.

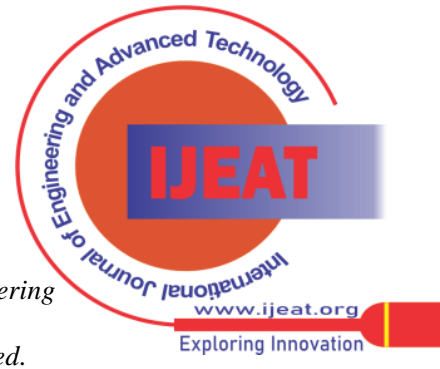




\section{RESULT AND DISCUSSION}

Case I Stress values for moving load condition and location of critical loading found out using Kenpave software.

Table 8 stress values at different load positions

\begin{tabular}{|c|c|c|c|c|}
\hline Location of loading & & $\begin{array}{c}\text { Stress in y direction } \\
\left(\mathrm{KN} / \mathrm{m}^{2}\right)\end{array}$ & $\begin{array}{c}\text { Stress in y direction } \\
\left(\mathrm{KN} / \mathrm{m}^{2}\right)\end{array}$ & $\begin{array}{c}\text { principal stress } \\
\left(\mathrm{KN} / \mathbf{m}^{2}\right)\end{array}$ \\
\hline $\begin{array}{c}\text { 1)Load at starting } \\
\text { condition }\end{array}$ & $\begin{array}{l}\text { Min } \\
\text { Max }\end{array}$ & $\begin{array}{l}-9583.5 \\
123.33\end{array}$ & $\begin{array}{l}-650.83 \\
670.20\end{array}$ & $\begin{array}{l}1.4559 \\
10276\end{array}$ \\
\hline $\begin{array}{l}\text { 2)Load at } \\
\text { middle } \\
\text { condition }\end{array}$ & $\begin{array}{l}\text { Min } \\
\text { Max }\end{array}$ & $\begin{array}{l}-5522.8 \\
56.869\end{array}$ & $\begin{array}{l}-390.75 \\
387.82\end{array}$ & $\begin{array}{l}1.2962 \\
6025.4\end{array}$ \\
\hline $\begin{array}{l}\text { 3)Load at } \\
\text { end } \\
\text { condition }\end{array}$ & $\begin{array}{l}\text { Min } \\
\text { Max }\end{array}$ & $\begin{array}{l}-5623.0 \\
60.904\end{array}$ & $\begin{array}{l}-387.89 \\
435.16\end{array}$ & $\begin{array}{c}0.35333 \\
6193.3\end{array}$ \\
\hline
\end{tabular}

Critical load considered for the condition when moving load starts moving on the pavement (i.e. case 1) because the stress values are higher for the First case.

Case II Pavement Section Is Suported on Varing Lengths

In the case of pavement section supported on varying lengths the negative bending moment, positive bending moment, and principal stress values are compared for all cases. And the support conditions are taken from $\mathrm{L} / 5$ to $\mathrm{L} / \infty$ (i.e. full area).
I. $L / 5$
II. $\mathrm{L} / \mathbf{1 0}$
III. $\mathrm{L} / 20$
IV. L/ $\infty$ (i.e. full area)

Stress value in different condition

Table 9 table of stress, bending and principle stress

\begin{tabular}{|l|c|c|c|c|}
\hline $\begin{array}{l}\text { Spacing of } \\
\text { support }\end{array}$ & Stress y direction \\
$\mathbf{( \mathbf { N } / \mathbf { m } ^ { 2 } )}$ & $\begin{array}{l}\text { Bending in x z plane } \\
\left(\mathbf{N} / \mathbf{m}^{\mathbf{2}}\right)\end{array}$ & $\begin{array}{l}\text { principal stress } \\
\left(\mathbf{N} / \mathbf{m}^{\mathbf{2}}\right)\end{array}$ \\
\hline $\mathrm{L} / 5$ & Min & -1320.40 & -2921.2 & 48.179 \\
& Max & 466.86 & 2615.5 & 7992.70 \\
\hline $\mathrm{L} / 10$ & Min & -1423.40 & -2212.2 & 38.179 \\
& Max & 362.86 & 1915.2 & 6592.70 \\
\hline Full area & Min & -1521.4 & -1926.4 & 32.149 \\
& Max & 266.46 & 1605.1 & 4692.9 \\
\hline
\end{tabular}

Where $\mathrm{l}=9.5 \mathrm{~m}$ and spacing support along the length

From the stress values for different supporting conditions the stress values decrease from $\mathrm{L} / 5$ to $\mathrm{L} / \infty$ (i.e. full area). Minimum when there is full area support i.e. when the DLC layer and Subgrade layers are compacted properly the stresses will be minimum.
Case III Parametric variation in the pavement section

A) Variation in the thickness of the pavement quality concrete (PQC)

1) Using ANSYS 12.1

Table 10 variation in principle stress Ansys

\begin{tabular}{|l|c|c|c|c|c|}
\hline $\begin{array}{l}\text { Pavement thickness } \\
(\mathrm{m})\end{array}$ & 0.16 & 0.20 & 0.24 & 0.28 & 0.32 \\
\hline $\begin{array}{l}\text { Principle stress } \\
\left(\mathrm{KN} / \mathrm{M}^{2}\right)\end{array}$ & 60.76 & 48.91 & 40.23 & 35.23 & 31.9 \\
\hline
\end{tabular}

2) Using KENPAVE

Table 11 variation in principle stress Kenpave

\begin{tabular}{|l|c|c|c|c|c|}
\hline $\begin{array}{l}\text { Pavement thickness } \\
(\mathrm{m})\end{array}$ & 0.16 & 0.20 & 0.24 & 0.28 & 0.32 \\
\hline $\begin{array}{l}\text { Principle stress } \\
\left(\mathrm{KN} / \mathrm{M}^{2}\right)\end{array}$ & 49.242 & 47.47 & 44.084 & 38.994 & 32.332 \\
\hline
\end{tabular}

As the thickness of the Pavement increases the principal stresses are decreasing proportionally.
B) Variation in thickness of dry lean concrete (DLC)

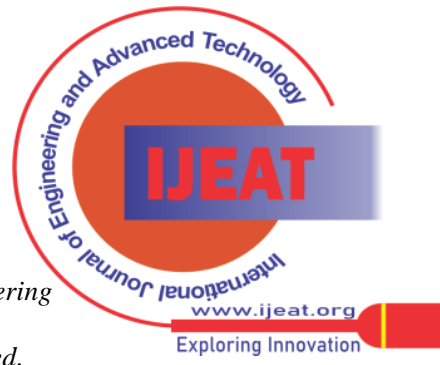


Optimum Pavement Thickness for Rigid Pavement in UP Eastern Region

Table 12 variation of stress in DLC layer

\begin{tabular}{|c|c|c|c|c|c|c|c|c|c|c|c|}
\hline $\begin{array}{l}\text { Thicknes } \\
\text { s of DLC } \\
\text { layer }\end{array}$ & $10 \mathrm{~cm}$ & $11 \mathrm{~cm}$ & $12 \mathrm{~cm}$ & $13 \mathrm{~cm}$ & $14 \mathrm{~cm}$ & $15 \mathrm{~cm}$ & $16 \mathrm{~cm}$ & $17 \mathrm{~cm}$ & $18 \mathrm{~cm}$ & $19 \mathrm{~cm}$ & $20 \mathrm{~cm}$ \\
\hline $\begin{array}{l}\text { principle } \\
\text { stress in } \\
\mathrm{kn} / \mathrm{m}^{2}\end{array}$ & 50.361 & 50.233 & 50.081 & 49.902 & 49.696 & 49.46 & 49.194 & 48.897 & 48.568 & 48.206 & 47.811 \\
\hline
\end{tabular}

In which first row thickness of the DLC layer and second row is the principle stress in $\mathrm{kn} / \mathrm{m}^{2}$

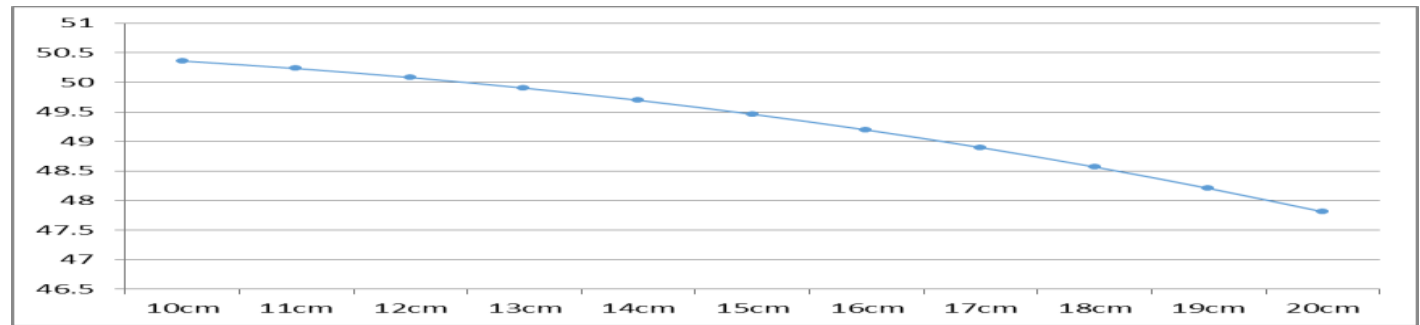

Fig 8 change in value of principle stress due to variation in DLC thickness variation

As the thickness of the DLC layer increases to the principle stresses decrease.

C) Variation in modulus of elasticity
In the standard condition of PQC layer thickness $320 \mathrm{~cm}$, Poisson ratio of .15 and Variation range of modulus elasticity 2.0E07 to 3.0E07

Table 13 variation in principle stress due to change in Poisson ratio

\begin{tabular}{|l|r|r|r|r|r|r|r|r|r|r|}
\hline $\begin{array}{l}\text { No in } \\
\text { graph }\end{array}$ & 1 & 2 & 3 & 4 & 5 & 6 & 7 & 8 & 9 \\
\hline $\begin{array}{l}\text { Modulus } \\
\text { of } \\
\text { elasticity }\end{array}$ & $2.00 \mathrm{E}+0$ & 7 & $2.10 \mathrm{E}+0$ & 7 & $2.20 \mathrm{E}+0$ & 7 & $2.30 \mathrm{E}+0$ & 7 & $2.40 \mathrm{E}+0$ \\
7 & $2.50 \mathrm{E}+0$ & 7 & $2.60 \mathrm{E}+0$ & $2.70 \mathrm{E}+0$ & 7 \\
7 & $2.80 \mathrm{E}+0$ \\
7 & $\begin{array}{r}2.90 \mathrm{E}+0 \\
7\end{array}$ & $\begin{array}{r}3.00 \mathrm{E}+0 \\
7\end{array}$ \\
\hline $\begin{array}{l}\text { Principal } \\
\mathrm{kn} / \mathrm{m}^{2}\end{array}$ & 36.655 & 38.055 & 39.425 & 40.767 & 42.082 & 43.372 & 44.636 & 45.876 & 47.093 & 48.288 \\
\hline
\end{tabular}

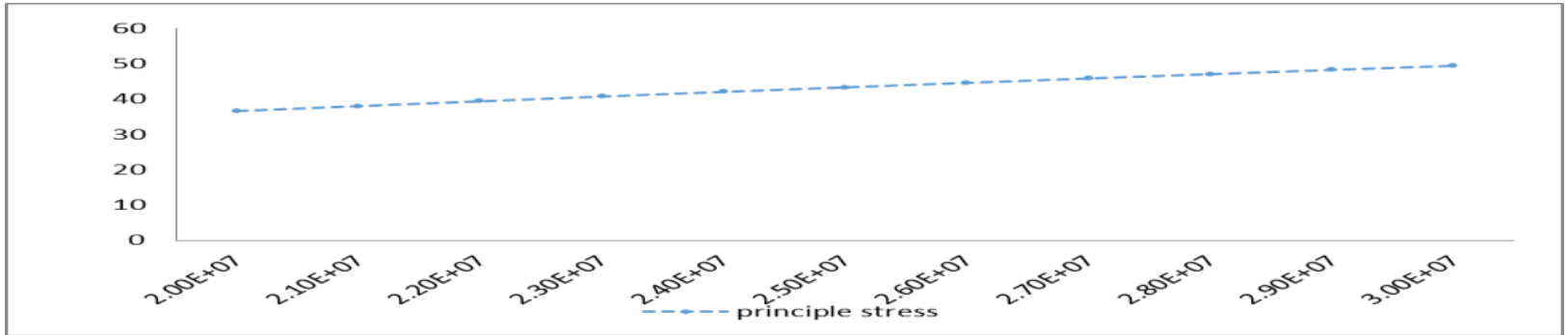

Fig 9 Variation in modulus of elasticity of PQC layer

As the modulus of elasticity increases the principal stresses also increases.

3. Variations in Poisson's ratio

Table 14 poison ratio vs principle stress in $P Q C \mathrm{kn} / \mathrm{m}^{2}$

\begin{tabular}{|l|l|l|l|l|l|l|}
\hline Poisson ratio & .15 & .16 & .17 & .18 & .19 & .20 \\
\hline $\begin{array}{l}\text { principle stress } \\
\text { in PQC } \mathrm{kn} / \mathrm{m}^{2}\end{array}$ & 49.46 & 49.567 & 49.681 & 49.803 & 49.933 & 50.071 \\
\hline
\end{tabular}

As the Poisson's ratio increases, the principal stresses values increases simultaneously.

\section{Variation in temperature}

Change in variation in temperature difference stress in pavement section stress is behaving nonlinearly

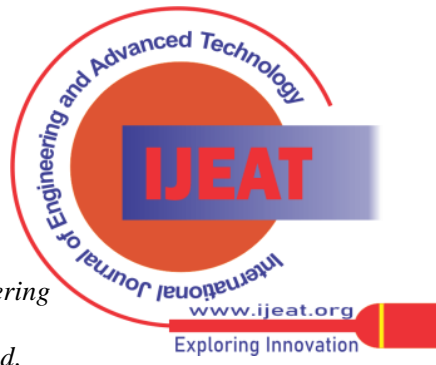


Table15 variation in stress value due to change in temperature difference

\begin{tabular}{|c|c|c|}
\hline Pavement thickness in cm & Principle stress $\left(\mathrm{kn} / \mathrm{m}^{2}\right) \quad$ P ${ }^{\circ} \mathrm{c}$ & 1303.528 \\
\hline $32 \mathrm{~cm}$ & 650.238 & 1295.192 \\
\hline $31 \mathrm{~cm}$ & 646.17 & 1286.06 \\
\hline $30 \mathrm{~cm}$ & 641.849 & 1278.106 \\
\hline $29 \mathrm{~cm}$ & 637.944 & 1269.096 \\
\hline $28 \mathrm{~cm}$ & 633.52 & 1258.987 \\
\hline $27 \mathrm{~cm}$ & 628.543 & 1247.7 \\
\hline $26 \mathrm{~cm}$ & 622.971 & 1235.125 \\
\hline $25 \mathrm{~cm}$ & 616.769 & 1221.266 \\
\hline $24 \mathrm{~cm}$ & 609.911 & 1205.964 \\
\hline $23 \mathrm{~cm}$ & 602.33 & 1189.137 \\
\hline $22 \mathrm{~cm}$ & 593.981 & 1170.737 \\
\hline $21 \mathrm{~cm}$ & 584.839 & 1150.582 \\
\hline $20 \mathrm{~cm}$ & 574.837 & 1128.637 \\
\hline $19 \mathrm{~cm}$ & 563.912 & 1104.691 \\
\hline $18 \mathrm{~cm}$ & 552.005 & 1078.697 \\
\hline $17 \mathrm{~cm}$ & 539.047 & 1050.424 \\
\hline $16 \mathrm{~cm}$ & 525.962 & 1019.738 \\
\hline $15 \mathrm{~cm}$ & 511.403 & \\
\hline & & \\
\hline
\end{tabular}

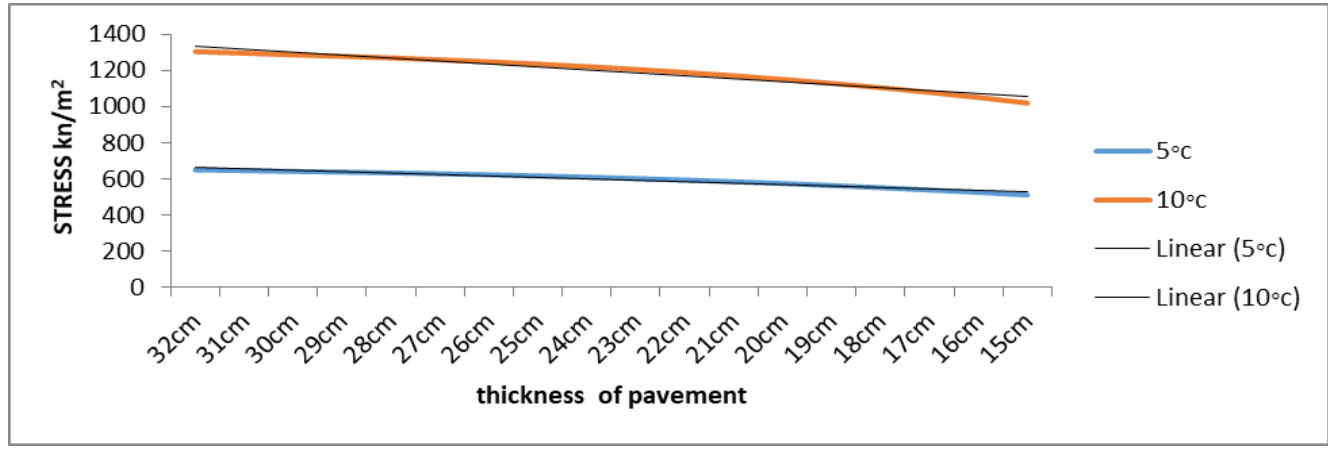

Fig. 10 variations in stress due to changes in temperature difference

At the higher temperature the stresses ere more (because at $10^{\circ} \mathrm{C}$ the stresses are more as compared to $5^{0} \mathrm{C}$ )

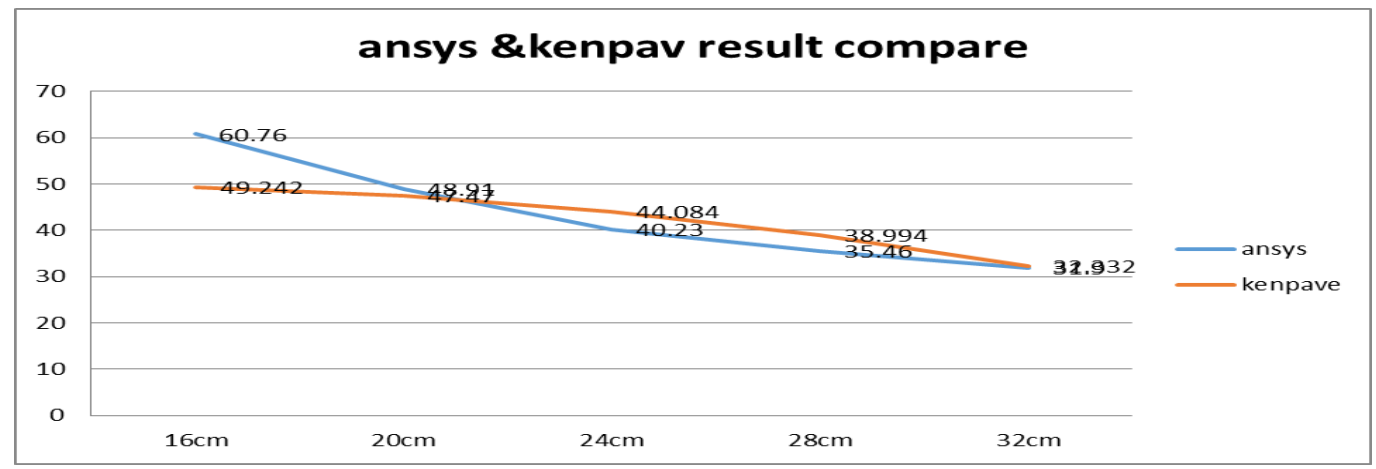

Fig 11 ANSYS and KENPAVEE result comparison

From the comparison graph the at $32 \mathrm{~cm}$ thickness the graphs are also overlapping.

\section{Case IV Cost Optimization}

Cost of the preparation 1cum PQC LAYER

PQC (with full cement) =4652 Rs. (as per NHI MANUAL)

Table 16 Cost effectiveness ratio

\begin{tabular}{|c|c|c|c|c|}
\hline Thickness & Flexural stress KN & Cost in thousands/block & Factor of safety & length cost /flexural stress \\
\hline $16 \mathrm{~cm}$ & 60.76 & 35 & 0.584266 & 0.576 \\
\hline $20 \mathrm{~cm}$ & 48.91 & 44 & 0.713556 & 0.8996 \\
\hline $24 \mathrm{~cm}$ & 40.23 & 53 & 0.837683 & 0.924986 \\
\hline $28 \mathrm{~cm}$ & 35.46 & 62 & 1.31 & 1.034483 \\
\hline $32 \mathrm{~cm}$ & 31.9 & 72 & 2.25 \\
\hline
\end{tabular}

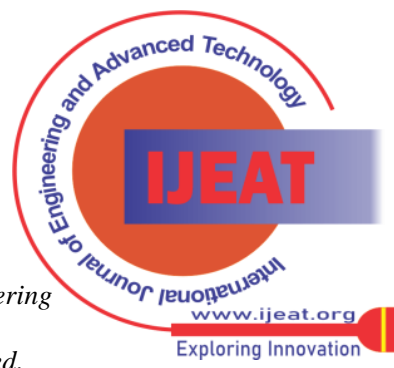




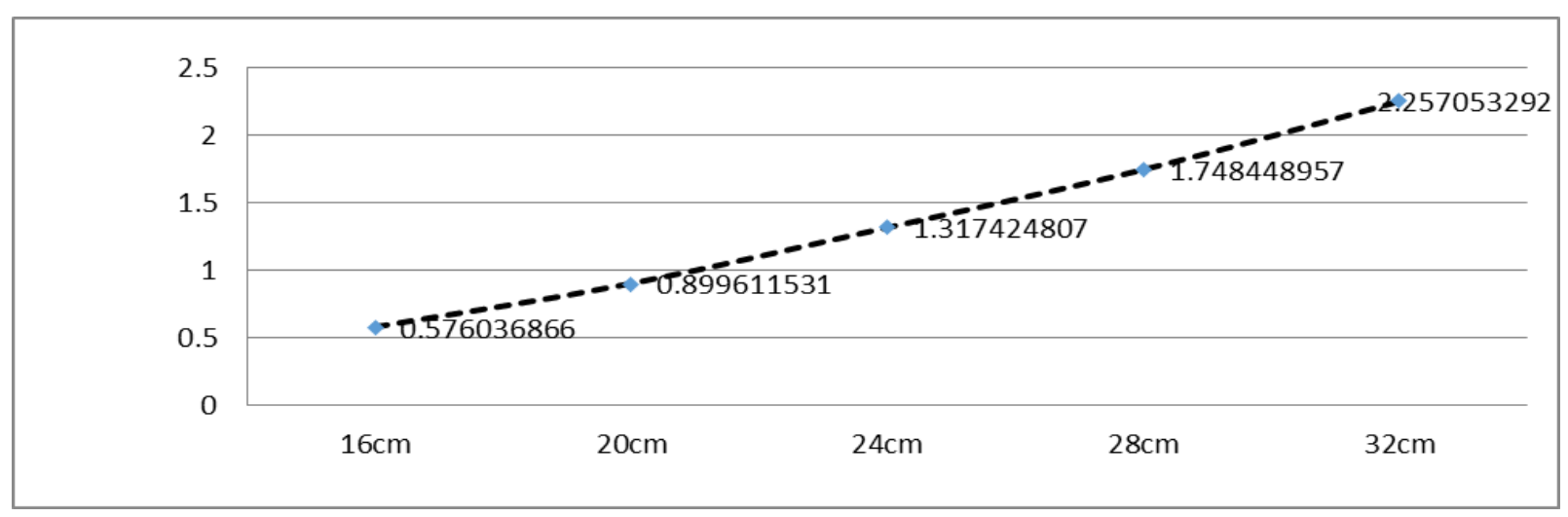

\section{Fig 12. Cost effectiveness ratio \\ (Length cost /flexural stress vs. Thickness of Pavement graph)}

As the thickness increases flexural stresses $(\mathrm{kN})$ decrease and the factor of safety increases.

From the above table, it is observed that the optimum thickness $32 \mathrm{~cm}$ in the rigid pavement because the factor of safety is also greater than one.

\section{CONCLUSIONS}

Some of the most important findings that evolved from this study are the following-

1) Critical load location can be located more accurately by the FEM method. For the design purpose, critical load considered for the condition when moving load starts moving on pavement.

2) Spacing of support is inversely proportional to the increase in stress and when the DLC layer and Subgrade layers are compacted properly the stresses will be minimum.

3) Thickness of the PQC layer and DLC layer is inversely proportional to an increase in stress. Modulus of elasticity, Poisson's ratio, and the temperature is directly proportional to the stresses in the Pavement.

4) From all the cases $320 \mathrm{~mm}$ thickness of the PQC layer is the optimized thickness for the standard class-A loading for above-targeted conditions.

\section{REFRENCES}

1. M. Zdiri, N. Abriak, J. Neji, M. Ben Ouezdou 2009 "Modelling of the Stresses and Strains Distribution in an RCC Pavement Using the Computer Code Abaqus" Electronic Journal of Structural Engineering.

2. V.A. Patil, V.A. Sawant and Kousik Deb 2010 "Use of finite and infinite elements in static analysis of pavement" Interaction and Multiscale Mechanics, Vol. 3, No. 1 (2010)

3. Karirn Chatti, John Lysmer, Carl L. Monismith1994 "Dynamic Finite-Element Analysis of Jointed Concrete Pavements" Transportation Research Record Vol. 1449, pp. 79-90 (1994).

4. S. N. Shoukry, M. Fahmy, J. Prucz and G. William 2007 "Validation of 3DFE Analysis of Rigid Pavement Dynamic Response to Moving Traffic and Nonlinear Temperature Gradient Effects" International Journal of Geomechanics, Vol.7

5. Ashraf R. Mohamed \& Will Hansen1995 "Prediction of Stresses in Concrete Pavements Subjected to Non-linear Gradients" Cement and Concrete Composites I8 (1996) 381-387

6. Lu Sun 2005 "Analytical dynamic displacement response of rigid pavements to moving concentrated and line loads" International Journal of Solids and Structures 43 (2006) 4370-4383

7. IRC-58-2002, Guidelines for the design of plain jointed rigid pavements for highways, second revision.

8. IRC-15-2002, Standard specification and code of practice for construction of concrete roads, third revision.

9. Programmer's manual for Ansys 002328-2007

10. .Huang, Y. H. (2004). Pavement Analysis and Design, Second
Edition. Upper Saddle River, NJ:07458 Prentice Hall.

11. Indian Roads Congress. (2016). Standard Specifications and Code of Practice for Road Bridges Section : Ii Loads and Load Combinations. Irc: 6-2016, 7, 1-107.

12. IRC-15.pdf. (n.d.).

13. Manjunatha, H. (2014). Laboratory Studies on Granular Sub Base. International Journal of Engineering Research and Technology, 3(4), 2535-2538.

14. Dr. S. K. Khanna \& Dr. C.E.O. Justo "Highway Engineering" 2001 edition.

15. Srikanth M R (2015) 'STUDY ON ANALYSIS OF FLEXIBLE PAVEMENT USING FINITE ELEMENT BASED SOFTWARE TOOL', International Journal of Engineering Research and, V4 (09), pp. 771-774. doi: 10.17577/ijertv4is090865.

16. Manjunatha, H. (2014). Laboratory Studies on Granular Sub Base. International Journal of Engineering Research and Technology, 3(4), 2535-2538.

\section{AUTHORS PROFILE}

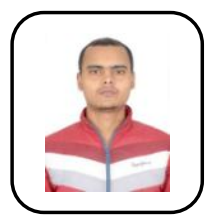

Shubham Pandey, received his B.Tech in civil engineering from S.R.M.C.E.M Lucknow in 2018. He is currently pursuing his masters in structural engineering from Motilal Nehru National Institute of Technology Allahabad Prayagraj, India. He is currently focusing on rigid pavements as part of his research. And have presented a paper on the topic "Study of Rigid Pavement for Varying Conditions Using KENPAVE" at an International conference on Futuristic Technologies -2021 at the Indian Institute of Technology Delhi.

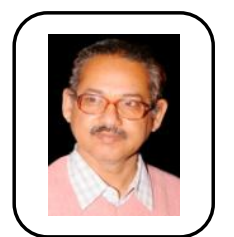

A. K. Sachan, is currently a Professor in the Department of Civil Engineering, Motilal Nehru National Institute of Technology Allahabad, Prayagraj, India. He has over 37 years of experience in teaching both Undergraduate and Postgraduate students. He obtained his B.E. degree in Civil Engineering from Rani Durgavati University, Jabalpur (GEC) in 1981. He did his M. Tech. degree in Structural Engineering from Institute of Technology, Banaras Hindu University, Varanasi, India (Currently IIT-BHU) in 1984 and Ph. D. from Kanpur University 1991. He has guided about $13 \mathrm{M}$. Tech. theses and $06 \mathrm{Ph} . \mathrm{D}$. thesis; and has published about 54 papers in International/National Journals and Conferences. His research areas include concrete, buildings, Health monitoring of Structures and Utilization of Waste Materials in construction.

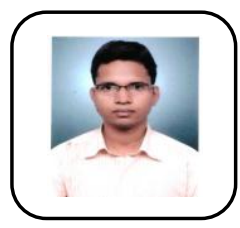

Anupam Rawat, is currently an Assistant Professor in the Department of Civil Engineering, Motilal Nehru National Institute of Technology Allahabad, Prayagraj, India. He has over 8 years of experience in teaching both Undergraduate and Postgraduate students. He obtained his B.E. degree in Civil

Published By: Blue Eyes Intelligence Engineering and Sciences Publication

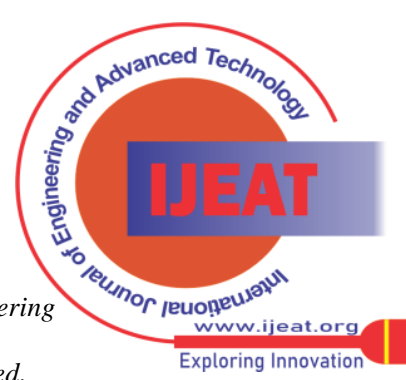


Engineering from Kamla Nehru Institute of Technology Sultanpur (UP), India 2009. He did his M. Tech. (2011) and Ph.D. (2017) degree in Structural Engineering from Motilal Nehru National Institute of Technology, Allahabad (UP), India. He has guided about 17 M. Tech. theses and 03 Ph.D. thesis; and has published about 34 papers in International/National Journals and Conferences. His research areas include Structural Health Monitoring, Ferro cement Structures, Soil Pavement Interaction, Concrete Structure ,Computational Analysis ,Non-Destructive Analysis.

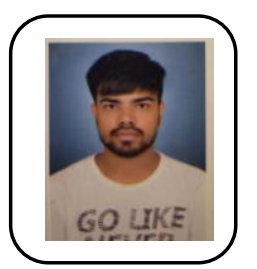

Saurabh Singh, received his B.Tech in civil engineering from Ajay Kumar Garg Engineering College, Ghaziabad in 2018. He is currently pursuing his masters in structural engineering from Motilal Nehru National Institute of Technology Allahabad, Prayagraj, India. He is currently focusing on smart sensors used in structural health monitoring along with rigid pavements as part of his research. And have presented a paper on the topic "Study of Rigid Pavement for Varying Conditions Using KENPAVE" at an International conference on Futuristic Technologies -2021 at the Indian Institute of Technology Delhi.

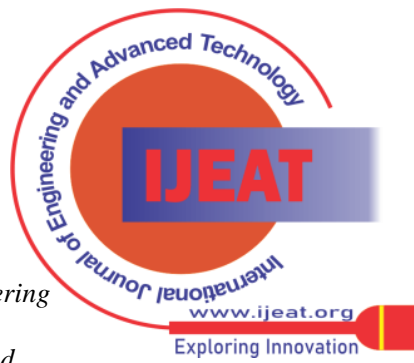

